\title{
Lexical Interference of Mandailing Language on Indonesian Language at Sitamiang Baru Padangsidimpuan
}

\begin{tabular}{|c|c|}
\hline & $\begin{array}{c}\text { Sumarsih }^{1} \\
{ }^{1} \text { Universitas Negeri Medan, Indonesia } \\
\end{array}$ \\
\hline ARTICLE INFO & ABSTRACT \\
\hline $\begin{array}{l}\text { Article history: } \\
\text { Received Aug 4, } 2020 \\
\text { Revised Sept 7, } 2020 \\
\text { Accepted Sept 17, } 2020\end{array}$ & \multirow{3}{*}{$\begin{array}{l}\text { The study aimed to analyze how the language lexical interference of } \\
\text { Mandailing Language on Indonesian language. The study conducted } \\
\text { descriptive qualitative research as a research method. The subject of } \\
\text { the study was the society at Sitamiang Baru, Padangsidimpuan. The } \\
\text { techniques of collecting data were interview and recording. In } \\
\text { addition, the data were analyzed based on Miles and Huberman in } \\
\text { Sugiyono (2016: 338) who said that the steps of analyzing data are; } \\
\text { 1) data reduction; 2) data display; 3) conclusion drawing/verification. } \\
\text { The result of the study showed that Interference at group vocabulary } \\
\text { level, i.e. lexical interference in the form of words basis and lexical } \\
\text { interference in the form of repeat words. It means that the society } \\
\text { tried to speak by using Indonesian language however, there are some } \\
\text { interferences which make the language is interfered by Mandailing } \\
\text { language. }\end{array}$} \\
\hline $\begin{array}{l}\text { Keywords: } \\
\text { Interference, } \\
\text { Mandailing, } \\
\text { Indonesian, } \\
\text { Lexical }\end{array}$ & \\
\hline Clonflict of Interest: & \\
\hline
\end{tabular}

None

Funding:

None

Corresponding Author: Prof. Dr. Sumarsih, Universitas Negeri Medan. E-mail: prof.sumarsih@gmail.com.

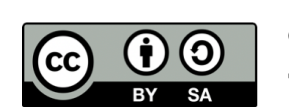

(C) Sumarsih

This is an open access article under the CC BY-SA 4.0 international license.

\section{Background of Study}

Language is nothing without society. Language is a tool to communicate something to the hearer. Language is integrally intertwined with our notions of who we are on both the personal and the broader, societal levels. When we use language, we communicate our individual thoughts, as well as the cultural beliefs and practices of the communities of which we are a part: our families, social groups, and other associations. Owen (2006) stated that the language as a socially shared those combinations of symbols and rule governed. Henry sweet, an English phonetician and language scholar, stated that language is the expression of ideas by means of speech sounds combined into words, words are combined into sentences, this combination answering to that of ideas into thoughts. Languages existed since the dawn of time and were used by people throughout history to communicate and build relationships.

Indonesian language has an important position namely as national language. Besides that, Indonesia is also well known as a country in many diversity. One of them is language. Based on Kemendikbud (2018), there are 652 regional languages in Indonesia. It shows that Indonesia people are able to speak in two or more than languages which are Indonesian and regional language. Therefore, Indonesian society is a multi linguist society. As a multi linguist society, Indonesian people use two or more than languages such as regional language as a mother language, Indonesian language as national language, and a foreign language. Indonesian as a national language and regional languages are used by the community to interact among ethnic group members. Indonesian is one of the Indonesian nation's identity. The identity of the Indonesian nation is not only based on the Indonesian language as the language national, but also supported by regional 
languages. Therefore, Indonesian can be nurtured and developed through the languages regions. Regional languages can serve as; (1) the symbol of nationality region, (2) the symbol of regional identity, (3) the means of communication within families and communities, (4) cultural development and support tools area.

As a diversity country, Indonesian people used to use merge languages in the same situation. Since people use and learn languages, contact is ought to occur and mistakes emerge. The difference between the first language (11) and the second language (12) leads to interference. Havlaskova (2010) described interference as a phenomenon that may occur at the level of a word, a phrase, an idiom, a metaphor or a term of a whole syntactic structure when translators transfer some source texts into target texts influenced by aspects of the source language. This term is seen by others as the influence of the native language (11) on the learning of the second language (12) and the transfer that occurs (erarslan \& hol, 2014).

In using language, of course we also talk about the variations and functional varieties of language because language is a social phenomenon. The study of language variation is an important part of sociolinguistics to the extent that requires references to social factors. Languages vary from one place to another, from one social group to another, and from one situation to another.

One of language known in Indonesia is Batak which is divided into several parts they are batak mandailing, angkola, toba, pakpak, simalungun and Karo.

The study focused on Mandailing language in Padangsidimpuan, North Sumatera. Based on Law Number 4 of 2001, the City of Padangsidimpuan is determined as an Autonomous Region and is the result of the merger of the Sub District of Padangsidimpuan Utara, Padangsidimpuan Selatan, Padangsidimpuan Batunadua, Padang Sidempuan Hutaimbaru, and Padangsidimpuan Tenggara which previously entered the territory South Tapanuli Regency (Padangsidimpuan.go.id, 2018). Then, the dominant dominant society of Padangsidimpuan is Mandailing and Angkola. However, it doesn't make the society keep speaking by using regional languages. The society also tended to use Indonesian language as their daily communication especially in Sitamiang Baru, Padangsidimpuan Selatan sub district. Sitamiang Baru is dominantly lived by Mandailing language which also tends to use Indonesian language in daily communication. Therefore, based on the current situation, it may have been interfered by the language around like Mandailing and Indonesian language. It is a phenomenon when Mandailing language is interfered into Indonesian language. It is because of there are also java people who live in Sitamiang Baru who make them tend to speak Indonesian language. Whereas, the language users use first language (L1) as Indonesian Language and second language (L2) is the Mandailing language. The interference happened because the L1 users lived at Sitamiang Baru which tend to speak in national language but its society is dominantly Mandailing language which make Mandailing language is interfered in Indonesian itself. For example, when someone wants to speak Indonesian language, it is interfered by Mandailing itself. For example, "kalo sonang kau kan". kalo is Mandailing language which means if, sonang means happy then kau kan is Indonesian language. Thus, there is interference of Mandailing language into Indonesian language which makes the characteristic of Padangsidimpuan language especially at Sitamiang Baru. Since the words sonang and kalo are interfered from senang (Indonesian) and kalau (Indonesian).

The kind of interference above is lexical interference. Dweik (2017) stated that lexical interference occurs mainly because of literal translation of lexicons.

Therefore, the study aimed to analyze how the language interference of Mandailing Language on Indonesian language. Based on the findings of the study, it would known that there is interference language happened in the society as oral language. The study would only focus on lexical interference.

\section{Literature Review}

\subsection{Mother Tongue}

Mother tongue is a language which a person acquires in early years and which normally becomes their instrument of thought.According to UNESCO (2003), MT or first language (L1) is defined as the language that an individual uses for the very first time in life, that he/she uses the most in overall daily activities, in which he/she is well versed and identifies himself/ herself as belonging to a specific linguistic community and then to the wider society. For Skutnabb-Kangas (1981: 18) it is "the language one thinks, dreams and counts in".

\subsection{L1 Acquisition}

Every developmentally healthy human being has a first language. Often (but not always) this is the language that was learned during childhood - before puberty - and is the language that is most used and most comfortable for a given person. First languages are generally maintained for life, with little overt effort on the 
part of the speaker. This is because first languages are often woven into the personal and sociocultural identities of the native speaker, and he or she uses the language to think and to interact with family and other members of their cultural or ethnic group.

L1s are learned through a process known as first language acquisition, or FLA. This is a complex biological process which is still not yet entirely understood by the scientific community. Though the intricacies of first language acquisition are beyond the scope of this article, the most commonly agreed-upon aspects of FLA are as follows:

First Language Acquisition is the process of gaining the capacity to use human language, where previously no such capacities existed.

L1s are acquired automatically, without conscious effort.

L1s are learned before puberty, typically during infancy.

An acquired L1 is known at native proficiency. According to J. Joseph Lee's Article The Native Speaker, An Achievable Model? published in the Asian EFL journal, native speaker have proficiency represented by an "internalized knowledge" of several areas of language, including:

Appropriate use of idiomatic expressions

Correctness of language form

Natural pronunciation

Cultural context including "response cries", swear words, and interjections

Above average sized vocabulary, collocations and other phraseological items

Metaphors

Frozen syntax, such as binomials or bi-verbials

Nonverbal cultural features

Despite the fact that one's "native language" are referred to as his or her "first language", it is possible to have several "first languages", so long as they are learned prior to puberty. For example, children who grow up in households where two languages are spoken (typically in the case of parents of different linguistic backgrounds) may acquire each of those languages natively. These people are referred to as bilingual.

2.3L2 Acquisition

Second language acquisition (SLA) is the learning of any language in addition to the mother tongue. Second language acquisition also refers to one's introduction to a second language after having received native competence in a first language (Fromkin, Rodman \& Hyams, 2003). Ellis (1997) argued that the second language is not only the language learned or succeeding one's mother tongue but the third or fourth language is part of the second language acquisition.

Acquiring another or additional languages requires an individual to pass through the same stages as in learning their first language. However, some individuals find it difficult in learning another language especially the adults. It is essential that second language learners receive an enormous amount of exposure to the language for them to learn it (Krashen, 1981). There are some reasons why people learn the second or third language which include expanding their knowledge in communication system, feeling part of the society. Learning the second language requires time, effort and organization in order for the individual to learn the language. One needs to be fluent in the native language also. Generally, learning the mother tongue is not really difficult but rather, the skills in learning other language varies for the individual, their attitudes towards the language and motivation.

L2 can be acquired either formal or informal. Schools and language courses are the formal ways to acquire L2 and through walking on the streets and the community is where to acquire the informal way of L2 (Baker, 2011). People are knowing or learning more different language and culture everyday because the world is now globalized. Acquiring the second or third language is important because it increases the opportunities in employment (Baker, 2011). In view of this, it is therefore very essential to be aware of bilingualism and its contribution to peoples educational development in general. The next chapter further introduces the term bilingualism in more depth.

2.4The Language Interference

2.4.1Definition of Language Interference

ASHREJ Vol. 2, No. 2, 2020: $62-68$ 
According to Nababan cited in Muhyidin (2016), interference is a fairly common symptom in language change, since there is language contact in the present so it can be said that interference as the biggest, most important symptom of change, and most dominant in language. Interference is a barrier as due to the habit of using mother tongue (first language) mastering languages learned (second language). As consequently, there is a transfer or transfer negative elements from mother tongue to in the target language (Muhyidin, 2016).

Chaer (1998:159) clarified that interference term was firstly introduced by Weinrich to state a systemized change of certain language as a condition after the mentioned language interacted to elements of other language done by bilingual person. Interference refers to entering elements of certain language outside the understanding of other language e.g. put clause or phrases of Indonesia while a person is speaking deliberately in English. According to Ellis (1997), interference defines interference as 'transfer', which refers to "the influence that the learner's native language exerts over the acquisition of target language". He asserts that transfer is governed by learners' first language.

Interference term first used by Weinreich (1953: 1) in "Languages in Contact" to describe the change in the system of a language in relation to the contiguity of these languages with elements of other languages was conducted by bilingual. Weinreich tells that language interference also causes deviations. On his book, Language and Contact, he argues "those instance of deviation from the norm of either language which occurs in the speech of bilinguals as a result of their familiarity with more than one language, will be referred to as interference phenomena."

In the other hand, interference according to Ellis (1997: 51) refers to interference as 'transfer', which he says "the influence that the learner's first language exerts over the acquisition of a second language". He argues that transfer is governed by learners' perceptions about what is transferable and by their stage of development in second language learning. Then, Dulay, et al in Bhela (1999: 22) say "Interference as the automatic transfer, due to habit, of the surface structure of the first language into the surface of the target language". Interference can occur automatically when the speaker or writer habits include grammatically structure of the source language into the target language. This is due to the mastery of the mother tongue as well as more indepth than a second language or a foreign language. Thus, it can be concluded from some definitions above that interference is the impact from language contact and it is a phenomenon of the use of one language's substance into another language where the characteristics of the native language still appear in target language.

\subsubsection{Types of Interference}

Interference just can occur in all languages speech and it can be devided into several types. Weinreich (1953: 14-47) divides interference into three kinds; they are phonological, grammatical and lexical interference. Grammatical interference covers morphological interference and syntactical interference.

Grammatical interference occurs when a bilingual or a translator identifies the structure of source language and then applies it in target language. In addition, semantic interference occurs because a learner or a translator usually rely on the meaning from a dictionary or his/her current knowledge, and fail to consider the usage of the word in the context provided (Susanto, 2018). Furthermore, Lexical interference occurs in various cases, such as simple words and phrase. Lexical interference in the level of simple words relates to false cognate - is a word which has the same or very similar form in two languages, but has a different meaning in each (Richards and Schmidt, 2010).

Dweik (2017) stated that lexical interference occurs mainly because of literal translation of lexicons. Thorovský stated that lexical interference and classifies it according to the five categories mentioned above. "First, surface lexical interference occurs in those cases where the lexical unit of the source language visually, i.e. orthographically, resembles a certain lexical unit of the target language, which is not its equivalent (at least not in the given case)" (Thorovský 2009: 86). By surface lexical interference.

\subsection{The Factor of Language Interference}

Interference is a general problem that occurs in bilingualism. There are many factors that contribute interference (Weinrich, 1970:64-65): First, SPEAKER BILINGUALISM BACKGROUND. Bilingualism is the major factor of interference as the speaker is influenced by both of the source and the target language. Indonesia's student who is Javanese and is studying good Bahasa tends to put his Javanese language into Indonesia. Look the example, 'Andi, apakah kamu bisa mengerjakan soal matematika ini?" tanya guru. Then Andi answered, "Tidak bisa, Bu Guru, lha wong itu angel." The impression of 'Lha Wong' is usual in Javanese cultural insight. The word 'angel' means difficult in Bahasa, the student should reply his teacher 
with "Tidak bisa, Bu Guru, soalnya sulit'. Regarding this condition, the student is a second grade of elementary school.

Second, DISLOYALTY TO TARGET LANGUAGE. Disloyalty to target language will cause negative attitude. This will lead to disobedience to target language structure and further force the bilingualist to put uncontrolled structure of his first language elements to output in practicing words utterances both oral and written. Students whose language background of TL is limited tend to put words in sentences or oral in structure and sense of first language. For example is occurred in Facebook status made by an Indonesian, "So I must spirit." While the correct sentence is "I must keep my spirit."

Third, THE LIMITED VOCABULARIES OF TL MASTERED BY A LEARNER. Vocabularies of certain language mostly are about words of surroundings connected to life. Thus, a learner who is willing to master another language will meet new words differ from his native words. In order to be able to speak as natives of TL, vocabularies take a big role. The more vocabularies someone has, the better he masters TL. Foreign language learner will try to put deliberately his native word to state some points when he cannot find the best words of TL. For example, when an Indonesian wants to mention 'rambutan', he stills mention 'rambutan' when he speaks in English. Since there is no English word for 'rambutan'. It is also similar to translate the cultural words like "Mitoni", "Slametan", "Tahlilan" and "Ngruwat".

Fifth, PRESTIGE AND STYLE. Applying unfamiliar words (foreign words) during a communication practice which dominant words are languages of both speaker and receiver is something else. Those unfamiliar words usage is aimed to get a pride. Interference will appear s there are certain words even though the receiver probably cannot catch the real idea of the speech. The usual unfamiliar words usage will become a style of the user. Unfortunately, the user sometimes does not understand the real meaning whether the meaning is denotative or connotative. The common feature is that many language users put derivational affix -ization in every word. To note, affix -ization is an adopting and borrowing process from English to state nouns.

\subsection{Mandailing Language}

Mandailing or Batak Mandailing is an Austronesian language spoken in Indonesia, the northern island of Sumatra. It is spoken mainly in Mandailing Natal Regency, North Padang Lawas Regency, Padang Lawas Regency, and eastern parts of Labuhan Batu Regency, North Labuhan Batu Regency, South Labuhan Batu Regency and northwestern parts of Riau Province. It is written using the Latin script but historically used Batak script.

Mandailing is part of the Batak cluster in North Sumatra Province. The Mandailing is a majority in the regencies of South Tapanuli and Mandailing Natal and also in a few districts of Labuhan Batu Regency. They also live in the neighboring areas of Rokan Hulu, Riau Province and Pasaman, West Sumatra Province. The Mandailing are often called the South Tapanuli, after their main home area. This name (Tapanuli Selatan) is sometimes shortened to Tapsel. The Mandailing language is different than languages spoken by the surrounding people groups in the Batak cluster, such as the Angkola, Dairi, Toba, Simalungun, Karo, etc.

The Mandailing community has its own customs. The mother tongue of Mandailing Batak is called hata (language) Mandailing. The Mandailing Batak language is used as a means of daily communication, both at home and outdoors. In addition, Mandailing Batak language is also used in traditional ceremonies, rituals and other activities. Mandailing language has a specificity, both in terms of form, the process of word formation, the meaning of the word and based on the variety of usage. The table below shows some similarity words in those language but difference in their phonetic.

\section{Method}

The research was conducted by using descriptive qualitative research. This research is aimed to know the lexi cal interference of Mandailing language on Indonesian language. In this research, Cresweel (2013); Tavallaei \&Talib (2010) said that qualitative research is less focused on testing hypothesis and relationship between va riables, but the description, analysis and interpretation of a given phenomenon. Based on the definition above the research used qualitative research because this research identified about the phenomenon which is happen ed in the society, especially about the interference language of Mandailing on Indonesian language. The subj ect of the study was the society who lives at Sitamiang Baru Padangsidimpuan, North Sumatera. Then, the te chniques of collecting data ware interview and recording. In addition, in analyzing the findings, the researche $r$ was based on Miles and Huberman in Sugiyono (2016: 338) who said that the steps of analyzing data are; 1) data reduction (the process of classifying, arranging, or organizing data); 2) data display (the steps to show/ 
make the visual of the data in the form of chart, diagram, matrix, or graphic); 3) conclusion drawing/verificati on (the last step draw conclusion from the data shown in the data display)

\section{Results and Discussion}

Dweik (2017) stated that lexical interference occurs mainly because of literal translation of lexicons. In addition, Lexical interference occurs in various cases, such as simple words and phrase. Lexical interference in the level of simple words relates to false cognate - is a word which has the same or very similar form in two languages, but has a different meaning in each (Richards and Schmidt, 2010).

Based on findings of the study, lexical interferences were found based on oral language used by the society at Sitamiang Baru Padangsidimpuan, North Sumatera. Interference at group vocabulary level, i.e. lexical interference in the form of words basis and lexical interference in the form of repeat words. Interference in the form of basic words to speakers of bilingual local languages into Indonesian on a level lexical is seen in the following examples.

- Bisa sajo manyusun cerita.

- Karejoon lah dulu tugasmu!

- U kabari kau nanti ya!

- Mangkana jangan nakal kau ya!

Based on the examples above, the underlined words showed that there are some lexical interferences of Mandailing language on Indonesian language namely, sajo menyusun (a) is from saja menyusun in Indonesian language; karejoon is from kerjakan; $\mathrm{u}$ is from $\mathrm{ku}$; and mangkana is from makanya.

Therefore, the society tried to speak by using Indonesian language however, there are some interferences which make the language is interfered by Mandailing language.

\section{Conclusion}

Weinreich (1953) tells that language interference also causes deviations. On his book, Language and Contact, he argues "those instance of deviation from the norm of either language which occurs in the speech of bilinguals as a result of their familiarity with more than one language, will be referred to as interference phenomena." Furthermore, Dweik (2017) stated that lexical interference occurs mainly because of literal translation of lexicons.

The study aimed to analyze how the language interference of Mandailing Language on Indonesian language. The Mandailing community has its own customs. The mother tongue of Mandailing Batak is called hata (language) Mandailing. The Mandailing Batak language is used as a means of daily communication, both at home and outdoors. Based on the findings of the study, it would known that there are interference language happened in the society as oral language. The study would only focus on lexical interference.

Furthermore, Lexical interferences were found based on oral language used by the society at Sitamiang Baru Padangsidimpuan, North Sumatera. Interference at group vocabulary level, i.e. lexical interference in the form of words basis and lexical interference in the form of repeat words. It means that the society tried to speak by using Indonesian language however, there are some interferences which make the language is interfered by Mandailing language.

\section{References}

Chaer, Abdul. 1994. Linguistik Umum. Jakarta; Rineka Cipta.

Darko, Abena Acheampomaa. 2016. Language Acquisition: Acquiring Languages Beyond Knowledge in First Language. Thesis for B.A. degree International Studies in Education. Education in Department Name, University of Iceland School of Education

Dweik, Brader. 2017. Lexical and Grammatical Interference in the translation of Written Texts from Arabic into English. Academic Research International. Vol. 8(3). Page 65-70.

Ellis, R. 1997. Second Language Acquisition. Oxford: Oxford University Press.

Ellis, Rod. 1986. Understanding Second Language Acquisition. Oxford: Oxford University Press.

Kemendikbud.go.id. 2018. Badan Bahasa Petakan 652 Bahasa Daerah di Indonesia. Accessed from https://www.kemdikbud.go.id/main/blog/2018/07/badan-bahasa-petakan-652-bahasa-daerah-diindonesia on July 8th, 2020.

Muhyidin, Asep. 2016. Interferensi Bahasa Daerah terhadap Bahasa Indone-Sia Lisan Masyarakat Kabupaten Serang Provinsi Banten. Jurnal Membaca. Vol. 1 Page 1-10. 
Padangsidimpuan.go.id. 2018. Sejarah Padangsidimpuan. $\quad$ Accessed from https://padangsidimpuankota.go.id/profil/ on July 8th 2020

Putri martanti. 2011. An Analysis of Grammatical Interference in Articles of BERANI newspaper. Thesis. Jakarta: English Letters Department, Letters and Humanities Faculty, State Islamic University Syarif Hidayatullah Jakarta.

Richards, Jack C and Richard Schmidt, Longman Dictionary of Language Teaching and Applied Linguistics, 4th Ed., London: Pearson Education Limited, 2010.

Shastri, Pratima Dave. 2010. Communicative Approach To The Teaching Of English as A Second Language. Mumbai: Himalaya Publishing House.

Siregar, Ahmad Samin. 1977. Kamus Bahasa Angkola/Mandailing Indonesia. Jakarta: Pusat Pembinaan Dan Pengembangan Bahasa, Departemen Pendidikan Dan Kebudayaan.

Sugiyono, 2006. Statisktika Untuk Penelitian. CV. Alfabeta: Bandung

Sulinda. 2015. The Students' Interferences in Translating Thesis Abstract from Indonesian into English. English Applied Linguistic Study Program, Postgraduate School, State University of Medan.

Susanto, Adi. 2018. A Study of Language Interference in the Translation of Indonesian into English Texts: A Case Study of Fifth Semester Students at English Department of FKIP, University of Mataram in Academic Year 2017/2018. Mataram: Universitas Mataram.

Thorovský, Martin. 2009. Lexical Linguistic Interference in Translations of Science-Fiction Literature from English into Czech”. Ostrava Journal of English Philology, vol. 1Page. 86-98.

Nababan, P.W.J. 1993. Sosiolinguistik Suatu Pengantar. Jakarta: Gramedia. 